\title{
STUDI PARTISIPASI MASYARAKAT TERHADAP PELAKSANAAN PROGRAM PNPM MANDIRI DI SUMATERA BARAT
}

\author{
Ermayanti $^{1}{ }^{2}$, Hendrawati $^{3}$, Lucky Zamzami ${ }^{4}$
}

\begin{abstract}
This research article was conducted in the village of Sungai Beringin, Payakumbuh District, 50 Kota Regency. This regency is one of the best in West Sumatra, in the implementation of PNPM-MPd, especially in the village of Sungai Beringin. Achievements were obtained from this village is the improvement of the capacity of the community in physical and economic developing, women activities and helped the community to access the entire potential in the village of Sungai Beringin for realizing independent and prosperity of the community. This research used a qualitative approach, as a case of study with research focused to community participation into PNPM MPd levels, which these phenomena specifically attention about time, place and condition has happened in the village of Sungai Beringin. A result of the research shows that factors which influenced community participation can say still low. Planning of development participation is consistent and seriously from another side in PNPM MPd implementation, which consists of training of community empowerment, especially poverty community, internal factors which influenced are age, status, gender, jobs, and education. External factors also influenced all of the form and community participation level in meeting and discussion active in the meeting.
\end{abstract}

Keywords: PNPM-MPd, Poverty Household, Participation, Rural Development Community

\section{Abstrak}

Artikel tersebut merupakan hasil penelitian yang telah dilaksanakan di Nagari Sungai Beringin, Kec. Payakumbuh, Kab. 50 Kota. Kab. 50 Kota adalah salah satu kabupaten terbaik di Sumatera Barat dalam pelaksanaan (PNPM-MPd), dalam hal ini terletak di Nagari Sungai Beringin, Kec. Payakumbuh, Kab. 50 Kota. Prestasi yang diperoleh dari wilayah tersebut adalah peningkatan kapasitas masyarakat dalam mengembangkan kegiatan perekenomian pengembangan fisik dan kegiatan simpan pinjam perempuan dan membantu masyarakat mengakses seluruh potensi yang ada di nagari Sungai Beringin dalam mewujudkan masyarakat mandiri dan sejahtera. Metode penelitian memakai pendekatan kualitatif berupa Studi kasus. Fokus

\footnotetext{
${ }^{1}$ Dosen Jurusan Antropologi FISIP Universitas Andalas, Padang.

${ }^{2}$ Korespondensi Penulis, Email: ermayanti14@gmail.com

${ }^{3}$ Dosen Jurusan Antropologi FISIP Universitas Andalas, Padang

${ }^{4}$ Dosen Jurusan Antropologi FISIP Universitas Andalas, Padang

DOI: 10.25077/jantro.v20.n1.p33-43.2018

JANTRO ISSN: 2355-5963 (Online)

under Lisensi Creative Commons Atribusi-BerbagiSerupa 4.0 Internasional
} 
penelitian diarahkan pada partisipasi masyarakat terhadap pelaksanaan program PNPM Mandiri. Penelitian menunjukkan bahwa partisipasi masyarakat dalam pelaksanaan PNPM Mandiri masih rendah. Hal tersebut dipengaruhi oleh faktor internal dan faktor eksternal. Faktor internal yang mempengaruhi partisipasi masyarakat adalah umur, status, jenis kelamin, jenis pekerjaan, dan pendidikan. Faktor eksternal dalam bentuk dan tingkat partisipasi masyarakat dipengaruhi oleh respon, kehadiran dan keaktifan berdiskusi dalam pertemuan terhadap pelaksanaan program PNPM Mandiri.

Kata Kunci: PNPM-MPd, Rumah Tangga Miskin, Partisipasi, Pembangunan Masyarakat Desa

\section{A. PENDAhULUAN}

$\mathrm{D}$ alam konteks pembangunan na sional, pembangunan diarahkan pa da semua sektor dan di semua wilayah, termasuk di perdesaan. Pem bangunan desa penting dilakukan mengi ngat sebagian besar penduduk Indonesia bermukim di pedesaan. Pembangunan desa diharapkan dapat meningkatkan kualitas hidup warga desa. Sehu bungan dengan itu pembangunan yang dilakukan harus benar-benar menyentuh kepentingan masyarakat desa itu sendiri (Hagul, 1985). Menurut Lowa, bahwa pada dasarnya pembangunan masyarakat desa memiliki 2 sasaran, yakni sasaran jangka pendek dan panjang. Sasaran jangka pendek yaitu merangsang masyarakat untuk megambil tindakan segera dan nyata, sedangkan sasaran jangka pan jang, yakni membentuk rasa kepercayaan terhadap diri sendiri (Lowa, 1985; Ermayanti, 2015). Berkaitan erat dengan namanya partisipasi, masyarakat desa adalah salah satu faktor pendukung keberhasilan program-program pemba ngunan desa. Bahwa partisipasi masyarakat diperoleh jika program-program dalam pembangunan sesuai dengan kebutuhan masyarakat tersebut (Damanik \& Tahitu, 2007; Darmi, 2016).

PNPM Mandiri adalah salah satu program pembangunan untuk melaksa nakan proses pembangunan desa yang bertumpu pada pemberdayaan masya rakat. PNPM Mandiri ini sekaligus sebagai ruang belajar (lesson learned) dalam pengambilan keputusan secara demo kratis pada tahap perencanaan,

DOI: $10.25077 /$ jantro.v20.n1.p33-43.2018 JANTRO ISSN: 2355-5963 (Online)

under Lisensi Creative Commons Atribusi-BerbagiSerupa 4.0 Internasional pelaksanaan, pengawasan dan pengen dalian dalam setiap proses pembangunan yang melibatkan masyarakat secara aktif. Pelaksanaan PNPM Mandiri dirancang untuk memberdayakan masyarakat, dima na masyarakat diajarkan untuk berparti sipasi dalam proses pembangunan melalui organisasi (Maryuni, 2015). Tujuan umum dari program PNPM ini adalah meningkatnya kesejahteraan dan kesempatan kerja masyarakat miskin secara mandiri. Pemerintah berharap para pelaku PNPM-Mandiri dapat menjalankan tugas dengan baik sehingga program ini benar-benar dapat menanggulangi tingkat kemiskinan di Indonesia. Hal ini tentunya sangat terkait dengan kinerja para pemerintah pusat dengan pemerintah daerah yang mana keberhasilan suatu program pemerintah diukur dari kinerja pemerintahannya itu sendiri. Sehubungan dengan ini dana PNPM-Mandiri dari pusat telah diserahkan sepenuhnya kepada pemerintah daerah yang kemudian di kelola oleh pemerintah desa yang diberikan kepercayaan sepenuhnya untuk turut mensejahterakan masyarakatnya (Mardani \& Rodiyah, 2016).

PNPM Mandiri dianggap memiliki program-program untuk mempercepat penanggulangan kemiskinan secara terpadu dan berkelanjutan. Selama ini, pendekatan PNPM Mandiri kepada masyarakat dinilai berhasil. Beberapa keberhasilannya adalah berupa penye diaan lapangan kerja dan pendapatan bagi kelompok rakyat miskin, serta berhasil menumbuhkan kebersamaan dalam masyarakat. PNPM mandiri memiliki visi, 
yakni tercapainya kesejahteraan dan ke mandirian masyarakat miskin (Noor, 2014; Vibriyanti, 2015). PNPM Mandiri menitik beratkan pada pemberdayaan masyarakat sebagai pendekatan operasionalnya. PNPM Mandiri merupakan wahana pengem bangan kapasitas bagi masyarakat dan aparat pemerintah melalui pengambilan keputusan yang demokratis, baik dalam perencanaan, pelaksanaan maupun keberlanjutan manfaat kegiatan (Royat, 2007). 3 (tiga) pendekatan dalam program PNPM Mandiri, yakni (1) pendekatan yang terarah, dimana pemberdayaan masya rakat harus terarah dan berpihak kepada kelompok masyarakat miskin. (2), pendekatan kelompok, dimana secara bersama-sama masyarakat berusaha memecahkan masalah yang dihadapi. (3), pendekatan pendampingan, dimana da lam proses pembentukan dan penye lenggaraan kelompok masyarakat miskin perlu didampingi oleh pendamping yang profesional sebagai fasilitator, komunikator, dan dinamisator terhadap kelompok untuk mempercepat tercapainya kemandirian (Zamzami, 2012). Atas hal tersebut, PNPM Mandiri perlu membentuk Badan Keswadayaan Masyarakat (BKM). BKM ini dipilih oleh masyarakat sendiri, yang dimaksudkan untuk mewadahi potensi partisipasi masyarakat desa dalam pengelolaan pembangunan di pedesaan.

Di Propinsi Sumatera Barat, PNPM Mandiri mulai dilaksanakan sejak tahun 2007, yang sebelumnya mengadopsi sepenuhnya mekanisme dan prosedur Program Pengembangan Kecamatan (PPK). PNPM memprioritaskan kegiatan bidang infrastruktur desa, pengelolaan dana bergulir bagi kelompok perempuan, kegiatan pendidikan dan kesehatan bagi masyarakat di wilayah perdesaan un tuk mendorong masyarakat untuk terlibat dalam kegiatan secara partisipatif, mulai dari proses perencanaan, pengam bilan keputusan dalam penggunaan dan pengelolaan dana sesuai kebutuhan paling prioritas di desanya, sampai pada pelaksanaan kegiatan dan pelestariannya.

Salah satu wilayah Propinsi Sumatera Barat, yaitu Kabupaten 50 Kota di nyatakan memiliki Indeks Pembangunan
Manusia Kabupaten 50 Kota masih di bawah Indeks Pembangunan Manusia provinsi yakni 71,22 dibanding 72,27. Data dan permasalahan yang ditemui mengkategorikan Kabupaten 50 Kota masih tertinggal dengan tingkat kemis kinan tinggi, banyaknya anak putus sekolah, pengangguran di tengah potensi hasil dan produksi SDA yang cukup tinggi (Desyandri, 2014). Nagari Sungai Beringin Kec. Payakumbuh Kab. Lima Puluh Kota memiliki jumlah penduduk miskin $250 \mathrm{KK} / 756$ jiwa atau sekitar 38,94 \% dari jumlahpenduduk sekitar 2.855 jiwa atau $680 \mathrm{KK}$ (BPS, 2016). Angka kemiskinan di Nagari tersebut dikatakan tinggi dikarenakan sebagian besar penduduk berprofesi sebagai petani, baik sebagai pemilik, penggarap maupun buruh tani. Kemiskinan merupakan masalah yang dialami oleh Nagari Sungai Beringin sehingga berupaya meme cahkan persoalan kemiskinan dengan berbagai program dan salah satunya melalui PNPM Mandiri. Melalui programprogram PNPM Mandiri, BKM berusaha memecahkan persoalan kemiskinan dan memiliki fungsi sebagai wadah partisipasi masyarakat untuk memperjuangkan ke butuhan dan aspirasi masyarakat. Berdasarkan permasalahan tersebut, dapat dirumuskan bahwa bagaimana upaya BKM untuk menggerakkan partisipasi masyarakat dan memecahkan berbagai permasalahan yang dihadapi masyarakat untuk meningkatkan taraf hidup masyarakat di Nagari Sungai Beringin Kec. Payakumbuh, Kab. 50 Kota.

\section{B. METODE PENELITIAN}

$\mathrm{P}$ enelitian ini telah dilaksanakan di Nagari Sungai Beringin, Kec. Payakumbuh, Kab. 50 Kota, Propinsi Sumatera Barat. Alasan pemilihan lokasi penelitian sampai saat ini pelaksanaan program PNPM Mandiri terus berjalan oleh pemerintah daerah di wilayah ini, terutama dalam program kegiatan bidang infrastruktur nagari, pengelolaan dana bergulir bagi kelompok perempuan, kegiatan pendidikan dan kesehatan bagi masyarakat. Dengan penduduk miskin sekitar 38,94 \% di wilayah ini, maka 
pelaksanakan program PNPM mandiri dianggap mampu meingkatkan kesejah teraan masyarakat miskin, terutama pemberdayaan komunitas wanita dan Usaha Kecil Menengah melalui Badan Keswadayaan Masyarakat (BKM) yang ada di nagari tersebut. Penelitian ini merupakan penelitian dengan pendekatan kualitatif digunakan metode deskriptif interpretatif (Denzin \& Lincoln, 2005). Pilihan terhadap pendekatan kualitatif ini di dasarkan pada rumusan dan tujuan yang hendak dicapai dalam penelitian ini (Neuman, 2006). Oleh karena luasnya cakupan dan teknik dalam pendekatan kualitatif, maka penelitian ini cenderung menggunakan teknik penelitian grounded theory. Teknik grounded theory ini memungkinkan peneliti mengkaji secara mendalam apa yang terjadi. Berdasarkan fenomena yang diteliti, teknik ini mampu membuat model kategorisasi, proposisi dan dalil yang ditemukan guna mengembangkan konsep-konsep baru (Babbie, 2010). Pendekatan kualitatif dilakukan dengan menggunakan observasi langsung dan metode wawancara mendalam.

Untuk memberi penjelasan yang rinci terhadap masalah yang diteliti, perlu dikumpulkan data dari hasil wawancara mendalam (indepth interview) dengan informan. Disamping itu, dilakukan juga metode observasi terhadap realitas sosial yang berkaitan dengan tingkat pengetahuan, perilaku dan potensi sosial budaya yang ada pada masyarakat. Selin data primer, juga diperoleh melalui data sekunder, yakni data yang diperoleh sudah diolah, seperti dokumen-dokumen tertulis dan studi kepustakaan. Informan dalam penelitian adalah pengurus Badan Keswadayaan Masyarakat (BKM) yang terdiri dari ketua/sekretaris/bendahara, Anggota rumah tangga yang tergolong miskin. Disamping itu, pejabat pemerintahan nagari dan tokohtokoh masyarakat relevan juga untuk diwawancarai.

\section{HASIL TEMUAN}

$\mathrm{K}$ ondisi geografis nagari Sungai Beringin terdiri dari dataran rendah, daerah bergelombang sampai dengan perbukitan yang memiliki ketinggian hingga 250-650 meter di permukaan laut. Nagari Sungai Beringin memiliki luas wilayah $983 \mathrm{Ha}$ yang terdiri dari 4 jorong, yakni Jorong Lareh Nan Panjang, Jorong Koto Tangah, Jorong Tanjung Munti dan Jorong Guguk. Nagari Sungai Beringin berada dalam wilayah Kec. Payakumbuh. Nagari ini juga berbatasan dengan dengan Kabupaten Tanah Datar. Nagari Sungai Beringin terletak pada ketinggian 250-650 meter dari permukaan laut. Jarak dari ibukota Kecamatan adalah $7 \mathrm{Km}$, dari lbu kota Kabupaten 50 Kota adalah $28 \mathrm{Km}$, dan jarak dari lbu Kota Propinsi Sumatera Barat adalah $140 \mathrm{Km}$. Luas Nagari Sungai Beringin $983 \mathrm{Ha}$, dengan batas - batas sebagai berikut: sebelah Timur berbatasan dengan Nagari Kelurahan Talang, sebelah Barat berbatasan dengan Nagari Piobang, sebelah Selatan berbatasan dengan Nagari Koto Tangah Batu Hama dan sebelah Utara berbatasan dengan $\mathrm{Ke}$ lurahan Koto Panjang. Permukiman wilayah Nagari Sungai Beringin ber bentuk daerah perbukitan dan dataran yang bervariasi tingkat kemiringannya. Secara umum, kemiringan wilayah Nagari Sungai Beringin dibagi atas kemiringan 8$15 \%$, kemiringan $15-30 \%$, kemiringan $30-$ $45 \%$ dan kemiringan $>45 \%$. Nagari ini memiliki tingkat curah hujan sebesar 2733 $\mathrm{mm} /$ tahun, dengan jjumlah bulan basah adalah 10 bulan/tahun dengan 2 bulan kering/tahun. Pada bulan Agustus, Nagari Sungai Beringin berada pada musim hujan, dengan kondisi iklim tropis, dimana suhu udara pada kawasan ini berkisar antara $22^{\circ} \mathrm{C}-29^{\circ} \mathrm{C}$.

Nagari Sungai Beringin berpenduduk 2.741 jiwa, yang terdiri dari 1.222 laki-laki dan 1.519 perempuan, dalam 764 Kepala Keluarga. Pekerjaan yang digeluti oleh Penduduk Sungai Beringin adalah 25,7 \% Petani/Peternak, $1 \%$ Pedagang, 0,9\% PNS, 0,5 \% Pegawai Swasta, $0 \%$ TNI/Polri, 2,3 \% Tukang, 0,2 \% Bidan, $0,5 \%$ Pensiunan, 9,6 \% Pengrajin dan Sisanya adalah pelajar/mahasiswa. Di Nagari Sungai Beringin, sarana pendidikan yang tersedia sebanyak 3 unit untuk SD, sedangkan yang paling sedikit yaitu bangunan TK. Sarana peribadatan berupa 1 unit mesjid dan 15 unit mushalla. Untuk sarana kesehatan di Nagari Sungai Beringin berupa Puskesmas, Polindes dan Posyandu.

DOI: 10.25077/jantro.v20.n1.p33-43.2018

JANTRO ISSN: 2355-5963 (Online)

under Lisensi Creative Commons Atribusi-BerbagiSerupa 4.0 Internasional 
Masyarakat Nagari Sungai Beringin menganut sistem kekerabatan Matrilineal, yakni hubungan kekerabatan dari pihak Ibu. Masyarakat daerah ini hampir selu ruhnya pemeluk agama islam kecuali beberapa pendatang. Masyarakat disini bisa dikatakan dengan pemeluk agama yang cukup fanatik yang memegang erat aturan-aturan yang ditetapkan oleh Islam dan mengamalkan dalam kehidupan sehari-hari. Walaupun adat-istiadat masya rakatnya masih kental, masyarakat di kecamatan ini selalu bersikap ramah dan terbuka. Pada kegiatan- kegiatan ini, para anak nagari selalu diberikan bimbingan serta kegiatan yang sifatnya positif agar budaya asli nagari tidak akan terlupakan dan terhapuskan akibat dari budaya luar.

Pada umumnya masyarakat Sungai Beringin bergerak disektor pertanian/ peternakkan dan kerajinan. Dewasa ini ekonomi masyarakat berangsur membaik. Hal ini disokong oleh adanya irigasi yang baik serta bantuan - bantuan permodalan dari Pemerintah dan Lembaga Keuangan lainnya. Disektor kerajinan, terutama di kerajinan songket merupakan primadona peoduksi kerajinan di Nagari Sungai Beringin. Hal ini tampak dari kegiatan pemuda pemudi Nagari Sungai Beringin disektor ini. Sokongan permodalan dari pemerintah dan Bank Dunia melalui PNPM Mandiri pun telah berhasil mendongkrak usaha ekonomi kerajinan ini.

Menurut hasil wawancara dengan lbu EY (52 tahun) sebagai pengurus BKM:

"PNPM ini diselengrakan oleh PU, kami yang BKM ini merupakan pelaksana progam. Untuk itu PNPM ini merupakan program yang di berikan kepada tiap nagari, untuk tingkat nagari ini ada BKM, kalau diatas kami ada juga pendamping yang mengawasi kami yang dipilih dari skopnya kecamatan dan terkahir ada koordinator kota. Untuk fasilitator pendamping kecamatan dan perkotaan ini direkrut oleh PU".

\section{Di Nagari Sungai Beringin, tujuan} umum PNPM Mandiri adalah meningkatkan kesejahteraan masyarakat miskin dan meningkatkan kesempatan kerja. Tujuan khusus PNPM Mandiri di
Nagari Sungai Beringin adalah meningkatkan t ing ka t partisipasi seluruh masyarakat, yakni masyarakat miskin, kelompok perempuan, komunitas adat terpencil, dan kelompok masyarakat lainnya yang belum dilibatkan secara optimal dalam proses pembangunan, peningkatan kapasitas kelembagaan masyarakat yang mengakar, representatif, dan akuntabel, dan peningkatan kapasitas pemerintah dalam memberikan pelayanan kepada masyarakat yang terbuka dan adil. Penentuan sasaran kelompok yang terkena program PNPM mandiri di Nagari Sungai Beringin berdasarkan atas musyawarah BKM antara pemerintah nagari dan masyarakat, melalui pertemuan-pertemuan yang dilaksanakan di kantor Wali Nagari. Dalam berbagai pertemuan tersebut akan diperoleh data mengenai tingkat kehadiran, respon dan tingkat keaktifan masyarakat dalam aktivitas tersebut.

\section{PEMBAHASAN}

$\mathrm{D}$ i nagari Sungai Beringin, PNPM Mandiri telah dilaksanakan dengan program pemberdayaan melalui tingkat partisipasi masyarakat. Untuk melihat tingkat partisipasi masyarakat tersebut perlu dilihat dari tahapan-ta hapan pelaksanaan program yang telah dilaksanakan. Tahapan-tahapan yang te lah dilaksanakan dalam pelaksanaan program PNPM mandiri adalah berupa kegiatan sosialisasi dan penyebaran informasi program, baik secara langsung melalui fórum-forum pertemuan maupun dengan mengembangkan/memanfaatkan media/saluran informasi masyarakat di berbagai tingkat pemerintahan. Kegiatan lainnya adalah pemetaan rumahtangga miskin dan Pemetaan Sosial (Hendrawati, 2016). Masyarakat diajak untuk bersamasama menentukan kriteria kurang mampu dan bersama-sama pula menentukan rumah tangga yang termasuk kategori miskin/sangat miskin. Masyarakat difasilitasi untuk membuat peta sosial nagari dengan tujuan agar lebih mengenal kondisi/situasi sesungguhnya nagari mereka, yang berguna untuk mengagas masa depan nagari, penggalian gagasan untuk menentukan

DOI: 10.25077/jantro.v20.n1.p33-43.2018

JANTRO ISSN: 2355-5963 (Online)

under Lisensi Creative Commons Atribusi-BerbagiSerupa 4.0 Internasional 
kegiatan yang paling dibu tuhkan, serta mendukung pelaksanaan kegiatan pembangunan dan peman tauannya.

Di tingkat unit terkecil dari Nagari adalah Jorong, dimana Jorong dapat memilih fasilitator nagari/kader pember dayaan masyarakat nagari untuk mendampingi proses sosialisasi dan perencanaan. Di samping itu, dilaksanakan juga proses seleksi untuk kegiatan yang menjadi prioritas di tingkat nagari dan kecamatan. Masyarakat melakukan musyawarah di tingkat nagari dan keca matan untuk memutuskan usulan kegiatan prioritas yang akan didanai. Musyawarah ini terbuka bagi segenap anggota masyarakat untuk menghadiri dan memutuskan jenis kegiatan yang paling prioritas/ mendesak. Keputusan akhir mengenai kegiatan yang akan didanai, diambil dalam forum musyawarah antarnagari di tingkat kecamatan, yang dihadiri oleh wakil-wakil dari setiap nagari dalam kecamatan yang bersangkutan.

Dalam forum pertemuan-pertemuan, masyarakat memilih anggotanya sendiri untuk menjadi tim pelaksana kegiatan di nagari Sungai Beringin untuk mengelola kegiatan yang diusulkan desa yang bersangkutan dan mendapat prioritas pendanaan program. Fasilitator teknis PNPM Mandiri akan mendampingi Tim Pelaksana Kegiatan dalam membuat sarana/prasarana, penganggaran kegiatan, verifikasi mutu dan supervisi. Para pekerja yang terlibat dalam pembangunan sarana/prasarana tersebut berasal dari warga setempat. Selama pelak sanaan kegiatan, tim pelaksana kegiatan harus memberikan laporan perkemba ngan kegiatan minimal dua kali dalam pertemuan terbuka nagari, yakni sebelum program mencairkan dana tahap berikutnya dan pada pertemuan akhir, dimana tim pelaksana kegiatan akan melakukan serah terima kegiatan kepada nagari, serta badan operasional dan pemeliharaan kegiatan atau Tim Pengelola dan Pemelihara Prasarana (TP3). PNPM Mandiri menyediakan dana langsung dari pusat (APBN) dan daerah (APBD) yang disalurkan ke rekening kolektif nagari di kecamatan. Masyarakat nagari dapat mempergunakan dana tersebut sebagai hibah untuk membangun sarana/ prasarana penunjang produktivitas desa, pinjaman bagi kelompok ekonomi untuk modal usaha bergulir, atau kegiatan sosial seperti kesehatan dan pendidikan. Setiap penyaluran dana yang turun ke masyarakat harus sesuai dengan dokumen yang dikirimkan ke pusat agar memudahkan penelusuran. Masyarakat nagari, dalam hal ini tim pelaksana kegiatan di tingkat kecamatan mendapat kan peningkatan kapasitas dalam pembukuan, manajemen data, pengarsipan dokumen dan pengelolaan uang/dana secara umum, serta peningkatan kapasitas lainnya terkait upaya pemba ngunan manusia dan pengelolaan pembangunan wilayah di nagari.

Pemerintah berperan sebagai pembina sekaligus pengontrol program PNPM mandiri. Untuk lebih memaksimalkan pembinaan dan pengontrolan itu, pemerintah di bagi dalam sebuah struktur organsasi dari tingkat daerah. Pemerintah juga berperan sebagai sebagai perumus kebijakan PNPM mandiri bertanggung jawab pada masyarakat atas keberhasilan program yang dilakukan. Untuk mendukung kebijakan PNPM mandiri ini, pemerintah menetapkan siklus pemberdayaan PNPM mandiri Pedesaan dan Perkotaan. Forum tertinggi pengambilan keputusan dan Unit Pengelola Kegiatan. Musyawarah antar kelurahan/ nagari dilakukan melalui musyawarah perencanaan pembangunan (musrembang) kecamatan reguler. Dalam musrembang ini perencanaan partisipatif PNPM mandiri melibatkan wakil-wakil masyarakat, termasuk dari badan keswadayaan masya rakat (BKM) untuk proses pengambilan keputusan.

Masyarakat dalam menanggapi pelaksanaan program PNPM mandiri ini saling bahu membahu untuk keberlangsungan program ini. Masyarakat sadar akan pentingnya program PNPM mandiri sebagai program pengentasan kemiskinan dan peningkatan kesejah teraan sehingga perlu dukungan secara fisik dari masyarakat itu sendiri. Masyarakat pada umumnya sangat setuju dengan program PNPM mandiri sebagai salah satu program pengentasan kemiskinan. Hal ini di karenakan kesadaran masyarakat akan perlunya pembangunan

DOI: 10.25077/jantro.v20.n1.p33-43.2018

JANTRO ISSN: 2355-5963 (Online)

under Lisensi Creative Commons Atribusi-BerbagiSerupa 4.0 Internasional 
sarana dan prasarana sebagai salah satu pondasi peningkatan kesejahteraan sudah mulai terbangun. Partisipasi masyarakat dalam pelaksanaan program PNPM mandiri ini terkait masalah penentuan program yang akan diajukan dan juga tekhnis pelaksanaan program itu sendiri. Hal ini merupakan sambutan positif dari masyarakat terhadap PNPM man diri dengan mengajukan program-program yang di rasa menjadi kebutuhan masyarakat itu sendiri.

Petugas Pelaksana kegiatan Program Nasional Pemberdayaan Masyarakat Mandiri (PNPM Mandiri) merupakan salah satu faktor dari kerhasilan atau kegagalan implementasi program PNPM Mandiri ini. $\mathrm{Hal}$ ini karena sangat pentingnya peran dari petugas pelaksana untuk melakukan sosialisasi program dan melakukan pendampingan terkait pelaksanaan program agar lebih efekti dan efisien. Pelaksanaan PNPM mandiri di nagari Sungai Beringin, Kecamatan Payakumbuh yang diharapkan mampu meningkatkan kesejahteraan masyarakat baik dengan peningkatan sarana prasarana yang mendukung produktifitas masyarakat maupun dari segi bantuan usaha bagi masyarakat, masih berfokus pada program perbaikan sarana prasarana. Dari beberapa pernyataan warga, sebagian besar masyarakat yang juga memiliki usaha kecil menengah Kurangnya informasi masya rakat terkait bantuan usaha dari program PNPM mandiri ini dapat dikarenakan; 1, memang tidak adanya sosialisasi itu, 2 kurangnya informasi yang diterima masyarakat terkait sosialisasi yang dilakukan. Hal ini menunjukan belum optimalnya peran dan fungsi dari petugas pelaksana itu sendiri.

Dengan jumlah keluarga yang ada berdasarkan data per tahun 2016, jumlah keluarga di nagari Sungai Beringin, Kecamatan Payakumbuh berdasarkan tingkat kesejahtera di bagi menjadi (1) keluarga Pra Kurang sejahtera sebanyak 269 Keluarga, (2) Kurang Sejahtera I sebanyak 266 Keluarga, (3) Kurang Sejahtera II+III sebanyak 46 Keluarga, (4) menuju Sejahtera + Sejahtera sebanyak 372 Keluarga. Data ini menun jukkan bahwa masih banyaknya keluarga yang di bawah garis kesejahteraan sehingga implementasi Program Nasional
Pemberdayaan Masyarakat Mandiri (PNPM Mandiri Pedesaan) merupakan program pemberdayaan yang diharapkan mampu meningkatkan kesejahteraan masyarakat. Bahwa masyarakat sadar akan penting nya program PNPM mandiri sebagai program pengentasan kemiskinan dan peningkatan kesejahteraan sehingga perlu dukungan secara fisik dari masyarakat itu sendiri. Masyarakat pada umumnya sangat setuju dengan program PNPM mandiri sebagai salah satu program pengentasan kemiskinan. Manfaat pembangunan sarana dan prasarana dengan adanya Program Nasional Pemberdayaan Masyarakat Mandiri (PNPM Mandiri) sebagai salah satu pondasi peningkatan kesejahteraan ini dirasakan secara langsung oleh masyarakat.

Implementasi program PNPM man diri di laksanakan menurut tahapantahapan pelaksanaan yang telah ditentukan oleh pemerintah pusat. Ketika ada masyaraka ataupun kelompok usaha masyarakat mengajukan proposal atas usaha yang ingin di kembangkan. PNPM mandiri diharapkan mampu meningkatkan kesejahteraan masyarakat baik dengan peningkatan sarana prasarana yang mendukung produktifitas masyarakat maupun dari segi bantuan usaha bagi masyarakat. Akan tetapi, program PNPM mandiri yang dilaksanakan di nagari Sungai Beringin, Kecamatan Payakumbuh masih belum maksimal. Untuk memak simalkan program PNPM mandiri ini, perlu di ketahui faktor pendukung sekaligus faktor penghambat pelaksanaan program agar dapat di jadikan bahan evaluasi.

Adapun faktor pendukung dan penghambat itu sebagai berikut: Adapun faktor pendukung dari program PNPM mandiri antara lain: (a) Tujuan dan sasaran kegiatan program PNPM Man diri yang jelas dan konsisten. Dalam program PNPM Mandiri di nagari Sungai Beringin, Kecamatan Payakumbuh ini, tujuan dan sasaran kegiatan di fokuskan pada upaya mewujudkan masyarakat yang berdaya dan mandiri yang sejalan dengan kebijakan Program PNPM mandiri sehingga dapat meningkatkan tingkat kesejahteraan. (b) Proses implementasi kegiatan PNPM mandiri ini memiliki dasar yang jelas sehingga dalam pelaksanaan PNPM mandiri di nagari 
Sungai Beringin, Kecamatan Payakumbuh ini sesuai dengan tahap pelaksanaan yang sudah di tetapkan oleh pemerintah. (c) Program PNPM mandiri Pedesaan ini mendapat respon yang baik dari petugas pelaksana maupun masyarakat. $\mathrm{Hal}$ ini terlihat dari kesadaran masyarakat akan pentingnya program PNPM mandiri sebagai bentuk upaya pemerintah dalam menangani masalah kemiskinan. (d) Pendanaan dari program PNPM mandiri selain dari APBN dan APBD juga mendapat bantuan serta pindaman dari sejumlah lembaga dan Negara dibawah koordinasi Bank Dunia dan dari CSR. (e) Pengajuan kegiatan PNPM mandiri diajukan oleh masyarakat sehingga sesuai dengan kondisi sosial masyarakat.

Adapun penyebab PNPM mandiri ini tidak maksimal dapat dikarenakan komitmen dan keahlian pelaksana program PNPM mandiri di nagari Sungai Beringin, Kecamatan Paya kumbuh ini masih belum optimal. Hal ini terlihat dari kurangnya sosialisasi yang intensif terkait program PNPM mandiri, tahapan pengajuan bantuan usaha yang dirasa terlalu panjang dan rumit dan pelaksanaan program PNPM mandiri yang masih mengekor pada kebijakan pemerintah pusat, kurang profesional nya petugas pelaksana program PNPM mandiri mulai dari tingkat nagari/kelurahan.

PNPM Mandiri yang ada di nagari Sungai Beringin, Kecamatan Payakumbuh menerapkan tiga tahapan dalam program penanggulangan kemiskinan yang melibat kan masyarakat dalam tahap perencanaan, tahap pelaksanaan dan tahap pemanfaatan. PNPM yang ada di nagari Sungai Beringin, Kecamatan Payakumbuh mengklasifikasikan program-programnya ke dalam tiga bidang yaitu bidang ekonomi, bidang sosial dan bidang lingkungan. Untuk bidang ekonomi, kegiatan dalam program ini yaitu memberikan pinjaman dalam bentuk sejumlah dana dengan jangka waktu pengembalian maksimum 1 tahun. Tujuan dari pelaksanaan program ekonomi bergulir ini adalah diharapkan program ini mampu menjadi kegiatan yang secara langsung memberikan manfaat dan peningkatan pendapatan bagi masyarakat atau kelompok. Kelompok swadaya masyarakat mempercayai seorang pe ngurus untuk bertanggung jawab dalam kegiatan ekonomi kemudian orang tersebut memilih lima sampai Sembilan masyarakat untuk membantu mengawasi kegiatan yang ada. Bidang sosial yaitu peralatan atau barang yang ada di PNPM nagari Sungai Beringin, Kecamatan Payakumbuh dapat di sewakan kepada masyarakat yang ingin meminjam kemudian hasil yang didapat di bagikan kepada masyarakat yang sudah lanjut usia (LANSIA) atau kepada anak yatim piatu yang sangat membutuhkan bantuan tersebut. Kelompok swadaya masyarakat mempercayai seorang pengurus untuk bertanggung jawab dalam kegiatan ekonomi kemudian orang tersebut memilih lima sampai sembilan masyarakat untuk membantu mengawasi kegiatan yang ada.

Bidang lingkungan yaitu kegiatan infrastruktur seperti pembangunan sarana jalan dan irigasi pertanian dengan tujuan peningkatan produksi pertanian berbasis komunitas. Kelompok swadaya masya rakat mempercayai seorang pengurus untuk bertanggung jawab dalam kegiatan ekonomi kemudian orang tersebut memilih lima sampai sembilan masyarakat untuk membantu mengawasi kegiatan yang ada. Proses perencanaan yang ada di PNPM nagari Sungai Beringin, Kecamatan Payakumbuh melibatkan masyarakat untuk ikut mengambil bagian dalam pertemuan karena masyarakat merupakan suatu alat ukur guna memperoleh informasi mengenai kondisi, kebutuhan dan sikap masyarakat setempat, masyarakat akan lebih memper cayai kegiatan pembangunan apabila mereka dilibatkan dalam persiapan dan perencanaannya karena mereka akan lebih mengetahui seluk beluk program tersebut dan akan mempunyai rasa memiliki terhadap program kegiatan tersebut.

Pelaksanaan pembangunan di mulai dari pencairan dana, mobilisasi tenaga kerja/bahan/alat, praktek kerja dilapangan, pelaksanaan kontruksi/ fisik,metode kerja, supervise pelaksanaan kontruksi, rapat evaluasi kemajuan lapangan,pemantauan dampak lingkungan kondisi $50 \%$ dan $100 \%$, dokumentasi kondisi $50 \%$ dan $100 \%$, perubahan pekerjaan dilapangan, penyelesaian pekerjaan kelompok

DOI: 10.25077/jantro.v20.n1.p33-43.2018

JANTRO ISSN: 2355-5963 (Online)

under Lisensi Creative Commons Atribusi-BerbagiSerupa 4.0 Internasional 
swadaya masyarakat dan pemeriksaan kegiatan.

Kehadiran masyarakat merupakan hal yang penting untuk menunjang keber hasilan suatu pembangunan. Waktu pelaksanaan kegiatan kegiatan yang ada di PNPM nagari Sungai Beringin, Kecamatan Payakumbuh selama 3 bulan. Keterlibatan masyarakat dalam memberikan sumba ngan merupakan hal yang penting karena masyarakat juga yang akan menikmati hasil pembangunan yang dibuat. Informan yang memberikan sum bangan (Uang, tenaga, material) sebanyak tiga kali yaitu ada enam responden, yang dua kali memberikan sumbangan ada dua responden dan yang 1 kali memberikan sumbangan ada dua responden. Partisipasi masyarakat dalam bentuk tenaga terhadap pelaksanaan pembangunan sarana jalan dan irigasi pertanian yang ada di nagari Sungai Beringin, Kecamatan Paya kumbuh yaitu sebagai buruh harian, masyarakat dalam hal ini bertindak sebagai buruh (tenaga kerja), yang mana atas jasa ini masyarakat di gaji sesuai dengan hari orang kerja (HOK). Menurut hasil penelitian, masyarakat memberikan sum bangan berupa tenaga ada yang menjadi mandor jika di uangkan sebesar Rp. 90.000. Tukang jika diuangkan sebesar Rp. 100.000. Pekerja jika di uangkan sebesar Rp. 80.000. kepala tukang jika di uangkan sebesar Rp. 120.000. Secara keseluruhan tenaga yang diberikan masyarakat dalam pembangunan jika diuangkan sebesar Rp. 870.000.

Adapun partisipasi masyarakat dalam bentuk bahan bangunan. Menurut hasil penelitian, masyarakat juga memberikan partisipasi berupa bahan bangunan untuk membantu pembangunan sarana jalan dan irigasi pertanian yang ada di nagari Sungai Beringin, Kecamatan Payakumbuh. Jika diuangkan, partisipasi masyarakat dalam bentuk bahan bangunan sebesar Rp. 4.418.641. Masyarakat juga memberikan partisipasi dalam bentuk administrasi seperti papan nama proyek, pelaporan, alat tulis kantor, dokumentasi, prasasti dan materai. Jika di uangkan partisipasi yang diberikan masyarakat sebesar Rp. 396.800. Selain memberikan partisipasi berupa tenaga, bahan bangunan dan administrasi ada juga masyarakat yang rela memberikan tanah dan tanaman yang mereka miliki untuk pembangunan sarana jalan dan irigasi pertanian. Masyarakat juga memberikan konsumsi berupa minuman, snack dan rokok kepada pekerja pada sore hari. Jika di uangkan partisipasi masyarakat sebesar Rp. 400.000.

\section{E. KESIMPULAN}

$\mathrm{S}$ alah satu prinsip pemberdayaan adalah menekankan adanya partisi pasi aktif dari masyarakat. Sesuai dengan pengertian partisipasi masyarakat, yakni keterlibatan masyarakat secara aktif dalam suatu kegiatan dengan men dukung pencapaian tujuan melalui pro ses pengambilan keputusan, pelaksa naan program, pemanfaatan ha sil dan mengevaluasi program. Bentuk partisipasi masyarakat dalam PNPM Mandiri terbagi mejadi empat (4) tahap yaitu:

- Tahap Pengambilan Keputusan; Pada tahap ini, keterlibatan masyarakat belum optimal, karena masih banyak masyarakat yang tidak ikut berpartisipasi dalam menghadiri rapatrapat maupun memberikan masukan nya. Pada tahap ini, partisipasi masyarakat berada pada tingkatan Decision Making atau membuat keputusan. Dimana masyarakat mencari kesepakatan bersama dengan tetap melihat prioritas kebutuhan masyarakat banyak.

- Tahap Pelaksanaan Program; Pada tahap ini, partisipasi masyarakat belum optimal dan menyeluruh dalam melak sanakan pembangunan fisik maupun pelatihan-pelatihan yang dilaksanakan dengan dikelurahan.

- Tahap Pemanfaatan Hasil; Pada tahap ini, keterlibatan masyarakat dikatakan optimal karena keterlibatan masyarakat sudah menyeluruh da lam memanfaatkan hasil dari pro gram ini. Keterlibatan masyarakat pada tahap ini lebih banyak dibandingkan tahap-tahap sebelumnya.

- Tahap Evaluasi; Pada tahap ini, partisipasi masyarakat berada pada tingkatan Self Management, dimana pada tahap ini masyarakat belajar untuk mengoptimalkan hasil serta mampu memelihara hasil kegiatan 
yang selama ini berlangsung. Keter libatan masyarakat juga dalam pembuat laporan pertanggungjawa ban untuk semua kegiatan yang dilakukan. Secara keseluruhan, partisi pasi masyarakat dalam program ini tergolong partisipasi dengan tipologi kemitraan (Partnersip). Pada tangga partisipasi ini, pemerintah dan masyara kat merupakan mitra sejajar yakni kekuasaan telah diberikan dan telah ada negosiasi antara masyarakat dan pemegang kekuasaan, baik dalam pengambilan keputusan, pelaksanaan, pemanfaatan maupun monitoring atau evaluasi.

Faktor-faktor yang menjadi penghambat partisipasi masyarakat dalam PNPM Mandiri, yakni: Keterbatasan dana. Dana untuk kegiatan pembangunan (fisik) dirasa kurang dan pembagian dana yang diberikan terbagi menjadi tiga tahap yang membuat pembangunan sempat terhenti sementara. Rendahnya Tingkat Kesadaran Masyarakat. Masih ada masyarakat yang menganggap bahwa PNPM Mandiri merupakan proyek dari pemerintah dan bukan kebijakan sehingga menyebabkan masyarakat kurang untuk ikut berpartisipasi. Lemahnya Pemahaman Masyarakat. Lemahnya pemahaman masya rakat pada saat pembuatan laporan administrasi yang dikarenakan tidak semua warga mendapatkan dan memiliki pendidikan yang cukup. Kesibukan Masyarakat. Kesibukan masyarakat yang tidak bisa meluangkan waktu untuk ikut berpartisipasi pada setiap kegiatan, padahal kegiatan tersebut akan memberikan manfaat bagi masyarakat banyak.

Partisipasi mayarakat terhadap BKM dalam pelaksanaan PNPM Mandiri di nagari Sungai Beringin, Kecamatan Paya kumbuh diwujudkan dalam pembentukan KSM, serta pembuatan proposal guna mengajukan usulan kredit untuk modal usaha walaupun ada sebagian masyarakat yang kesulitan dalam pembuatan dan perbaikan proposalnya, peran masyarakat juga diwujudkan dalam pelaksanaan program antara lain dengan mengikuti pelatihan pembuatan tempe serta mengajukan usulan program perbaikan infrastruktur jalan, serta sanitasi pembuangan air. Proses partisipasi masyarakat terhadap BKM dalam pelaksanaan PNPM mandiri di nagari Sungai Beringin, Kecamatan Payakumbuh adalah dengan menggalakkan pertemuan dan diskusi tentang PNPM mandiri, mengidentifikasi masalah, menentukan skala prioritas, membentuk kepanitiaan, mengimple mentasikan program, pelaporan, meningkatkan jalur komunikasi dan infor masi, pengoptimalan kinerja pengurus, dan strukturisasi. Kondisi masyarakat cukup terbantu dengan adanya PNPM mandiri karena bisa mengusulkan peminjaman modal untuk usaha dan dapat manfaat dari mengikuti pelatihan-pelatihan. Masya rakat juga menikmati fasilitas dari pembangunan jalan dan sanitasi.

\section{F. UCAPAN TERIMAKASIH}

$\mathrm{P}$ enulis mengucapkan terimakasih kepada Fakultas IImu Sosial dan IImu Politik yang telah menyediakan dana penelitian dasar keilmuan tahun anggaran 2017/2018 Nomor: 01/PL/SPK/ PNP/FISIP-UNAND 2017 Tanggal 01 Agustus 2017 dan tim peneliti sehingga pelaksanaan penelitian berjalan dengan lancar dan sukses.

\section{Daftar Pustaka}

Babbie, E. (2010). The Practice of Social Research - Earl R. Babbie - Google Kitaplar. https://doi.org/9780495598411

BPS. (2016). Kabupaten Limapuluh Kota dalam Angka.

DOI: 10.25077/jantro.v20.n1.p33-43.2018

JANTRO ISSN: 2355-5963 (Online)

under Lisensi Creative Commons Atribusi-BerbagiSerupa 4.0 Internasional 
Damanik, I. P. N., \& Tahitu, M. E. (2007). Studi Tingkat Partisipasi Masyarakat Dalam Pembangunan Desa (Kasus: Masyarakat Desa Layeni, Kecamatan Teon Nila Serua, Kabupaten Maluku Tengah)[Internet]. Jurnal Agroforestri, 2(1), 5-12.

Darmi, T. (2016). Optimalisasi Peran Perempuan Berbasis Modal Sosial Pada Sektor Pemerintahan Desa (Study pada Pengelolaan Dana Desa). Jurnal Antropologi: Isu-Isu Sosial Budaya, 18(1), 21-27. doi:https://doi.org/10.25077/ jantro.v18.n1.p21-27.2016

Denzin, N. K., \& Lincoln, Y. S. (2005). Qualitative research. Denzin, NK Y Lincoln YS, 2.

Ermayanti, E. (2015). Studi Pengembangan Kelembagaan Berdasarkan Kultur Masyarakat Lokal Pada Kelompok Nelayan. Jurnal Antropologi: Isu-Isu Sosial Budaya, 16(2), 149-165. doi: https://doi.org/10.25077/jantro.v16.n2.p149-165.2014

Hagul, P. (1985). Pembangunan desa dan lembaga swadaya masyarakat. Rajawali.

Hendrawati., \& ., E. (2017). Wanita Perajin Tenun Tradisional Di Nagari Halaban, Kecamatan Lareh Sago Halaban Kabupaten Lima Puluh Kota, Sumatera Barat. Jurnal Antropologi: Isu-Isu Sosial Budaya, 18(2), 69-87. doi:https://doi.org/10.25077/jantro.v18.n2.p69-87.2016

Mardani, Y., \& Rodiyah, I. (2016). Implementasi Program Nasional Pemberdayaan Masyarakat

Mandiri Perkotaan (PNPM-MP) di Desa Gisik Cemandi Kecamatan Sedati Kabupaten Sidoarjo. JKMP (Jurnal Kebijakan Dan Manajemen Publik), 4(1), 89-100.

Maryuni, S. (2015). Implementation Of The National Community Empowerment Program (Pnpm) In Pontianak. Spirit Publik, 10(1), 19-30.

Neuman, W. L. (2006). Social Research Methods: Qualitative and Quantitative Approaches.social research (Vol. 8).

Noor, M. (2014). Penanggulangan Kemiskinan Di Indonesia (Studi Tentang Program Nasional Pemberdayaan Masyarakat Mandiri Perkotaan Di Kota Semarang). Serat Acitya. Royat, S. (2007). Kebijakan Pemerintah dalam Penanggulangan Kemis kinan. In Materi Assisten

Deputi Menko Kesra Bidang Penanggulangan Kemiskinan pada Seminar Nasional: Meningkatkan Peran Sektor Pertanian Dalam Penanggulangan Kemiskinan, tanggal (Vol.21).

Suharsimi, A. (2010). Prosedur Penelitian: Suatu Pendekatan Praktik (Edisi Revisi). Jakarta: Rineka Cipta (Vol. 1). https://doi.org/10.1017/CBO9781107415324.004

Vibriyanti, d. (2016). Peran Kaum Perempuan Dalam Industri Kerajian Gerabah Di Desa Banyumulek, Lombok Barat, Nusa Tenggara Barat. Jurnal Antropologi: Isu-Isu Sosial Budaya, 17(2), 117-129. doi:https://doi.org/10.25077/jantro.v17.n2.p117129.2015

Zamzami, L. (2012). Peranan Lembaga Pengembangan Pesisir Mikro "Mitra Mina" dalam Upaya Pemberdayaan Ekonomi Masyarakat Pesisir di Sumatera Barat. Asian Journal of Innovation and Entrepreneurship, 1(2), 121-128. 